\title{
Measurable Biophysical Indicators for Impact Assessment: Changes in Soil Quality
}

\author{
P. Pathak, K.L. Sahrawat, T.J. Rego and S.P. Wani \\ International Crops Research Institute for the Semi-Arid Tropics (ICRISAT), \\ Patancheru, India
}

\section{Introduction}

Soil plays a key role as the interface between terrestrial and aquatic ecosystems on the one hand and the atmosphere on the other. The importance of soil in meeting food, feed and fibre needs and maintaining environmental sustainability cannot be overemphasised. A healthy or good quality soil acts as an environmental filter in cleaning air and water. Soil is a major sink for global gases and its appropriate management favourably affects the carbon dioxide $\left(\mathrm{CO}_{2}\right)$ balance that is important in combating global warming. If mismanaged, soil can work against us; it can pollute the air and water and lead to a fall in agriculture production.

Decline in soil quality has occurred worldwide, particularly in the semiarid tropical (SAT) regions and is manifested as adverse changes in physical, chemical and biological soil properties and its contamination by inorganic and organic chemicals (Arshad and Martin, 2002; Lal, 2004). In many parts of world production of major cereals is declining mainly due to soil degradation coupled with inadequate soil and water management (Steer, 1998).

Natural resource management (NRM) interventions in terms of fertility, soil and water management practices in various farming systems have become necessary to address the problem of soil degradation and hence increasing investments in NRM research and development are being made worldwide. To diagnose and quantify the impacts of various NRM interventions, reliable soil quality indicators are necessary. Impact assessment is essential for the development of suitable management strategies for soil quality and to maximise productivity and sustainability for the benefits of society.

Appropriate and measurable soil quality indicators are needed to assess the impact of various NRM interventions on soil quality in agricultural lands. Measurable and simple soil quality indicators are important because many of the conventional soil attributes used to characterise soils become useful only 
after soil degradation has already taken place. To have soil quality indicators together with the soil quality thresholds needed to monitor and assess the impact of NRM technologies seems rather a tall order. Modern agricultural practices used to intensify agriculture have complicated the selection of such indicators, but several measurable indicators are available and can be used to assess the biophysical impact of NRM practices. Unfortunately, there is no universal set of indicators that is equally applicable in all cases, so the selection of those relevant to specific conditions is extremely important.

The objective of this chapter is to identify and discuss with examples from recent literature the use of biophysical indicators in monitoring the impact of NRM interventions on soil quality attributes. The use of simulation modelling to assess the long-term effects of NRM interventions on soil quality and future research needs are also covered.

\section{Soil Quality Indicators}

Soil quality indicators are measurable soil attributes that influence the inherent capacity of the soil to perform its production and environment-related functions. Attributes that are management-responsive are most desirable as indicators. During the past 10 years many definitions of soil quality with similar elements have been proposed (Arshad and Coen, 1992; Doran and Parkin, 1994; Karlen et al., 1997). A recent definition was proposed by Karlen et al. (2003) and a committee of the Soil Science Society of America: "the fitness of a specific kind of soil, to function within its capacity and within natural or managed ecosystem boundaries, to sustain plant and animal productivity, maintain or enhance water and air quality, and support human health and habitation"; this seems to be inclusive and appropriate for the objectives of this chapter.

It should, however, be mentioned that the soil quality paradigm has received several criticisms because of its general lack of sufficient quantification and scientific rigour (Letey et al., 2003; Sanchez et al., 2003; Sojka et al., 2003). These authors believe that in assessing soil quality emphasis should be directed towards using available technical information to motivate and educate farmers on 'quality soil management' involving management practices that optimise the combined goals of high crop production, low environmental degradation, and sustained resource use (Sojka et al., 2003). However, several scientists believe that with further refinement, soil quality indicators could provide a more useful tool for assessing soil quality. It may be useful to note that indicators for monitoring soil quality could also help towards developing quality soil management.

Scientists aim to develop a set of basic soil characteristics to serve as key soil quality indicators (Stott et al., 1999) that are sensitive to climatic and management interventions. Ideally, the best soil quality indicators are those attributes or characteristics that show observable and significant changes between 1 to 3 years, with 5 years being an upper limit to usefulness. 
Given the complex nature of soil and the exceptionally large number of soil properties that may have to be determined, it is important to be able to select properties that are appropriate and practical. Stephen (2002) grouped attributes that can be used as indicators of soil quality into four broad groups: physical, chemical, biological and visible indicators. Karlen and Stott (1994) proposed a framework for evaluating physical and chemical indicators of soil quality. Turco et al. (1994) discussed the various microbial indicators of soil quality. Arshad and Martin (2002) proposed selected physical, chemical and biological soil quality indicators (Table 3.1). In the light of diverse soil functions for which indicators are used, the quality indicators listed may not be sufficient to evaluate the changes in soil quality resulting from various agricultural and NRM interventions. Depending upon the local conditions, some may have to be added or excluded. These are discussed in turn below.

Table 3.1. Selected physical, chemical and biological soil quality indicators used to assess soil quality.

\begin{tabular}{|c|c|}
\hline Soil quality indicator & Rationale for selection \\
\hline \multicolumn{2}{|l|}{ Physical } \\
\hline Top soil-depth & $\begin{array}{l}\text { Estimates moisture availability, rooting volume for crop production } \\
\text { and erosion }\end{array}$ \\
\hline Aggregation & $\begin{array}{l}\text { Indicates status of soil structure, erosion resistance, crop emergence } \\
\text { can be an early indicator of soil management effect }\end{array}$ \\
\hline Texture & Indicates retention and transport of water and chemicals \\
\hline Bulk density & Shows plant root penetration and air-filled porosity \\
\hline Infiltration & Indicates runoff, leaching and erosion potential \\
\hline $\begin{array}{l}\text { Biochemical } \\
\mathrm{pH}\end{array}$ & Indicates nutrient availability, sorption and desorption of molecules \\
\hline Organic matter & $\begin{array}{l}\text { Affects fertility, structure, water retention and sorption and } \\
\text { desorption of molecules }\end{array}$ \\
\hline Electrical conductivity & $\begin{array}{l}\text { Defines salt content, crop growth, soil structure and water } \\
\text { infiltration }\end{array}$ \\
\hline Suspended pollutants & Affects food quality, water quality and human and animal health \\
\hline Soil respiration & $\begin{array}{l}\text { Indicates biological activity, biomass activity and organic matter } \\
\text { quantity and quality }\end{array}$ \\
\hline Form of soil $\mathrm{N}$ & $\begin{array}{l}\text { Defines availability to crops, leaching potential, mineralisation/ } \\
\text { immobilisation rates }\end{array}$ \\
\hline Extractable $\mathrm{N}, \mathrm{P}$ and $\mathrm{K}$ & $\begin{array}{l}\text { Indicates capacity to support plant growth and serve as an } \\
\text { environmental quality indicator }\end{array}$ \\
\hline
\end{tabular}

Source: Adapted from Arshad and Martin, 2002 


\section{Physical quality indicators}

Physical indicators are principally concerned with the physical arrangement of solid particles and pores. They include soil texture, moisture-holding capacity, bulk density, porosity, aggregate strength and stability, crusting, surface sealing, compaction and depth.

\section{Chemical quality indicators}

The list of potential soil chemical indicators attributes is very large and the final selection will depend upon the soil function and process under consideration. These attributes include: $\mathrm{pH}$, salinity (electrical conductivity), organic matter content, cation-exchange capacity (CEC), plant nutrient status, concentrations of potentially toxic elements, and - possibly the most important attribute - the capacity of the soil to buffer against change.

\section{Biological quality indicators}

Biological parameters are relatively dynamic and sensitive to changes in both soil management and climate. This gives biological indicators a comparative advantage over physical or chemical parameters, so they can be used as indicators of soil quality at an early stage. Some of the parameters that could serve as such indicators are: populations of micro-, meso-, and macro-organisms, soil respiration rate, enzyme activities, rate of nutrient mineralisation, microbial biomass, and more detailed characterisation of soil organic matter fractions.

\section{Visible quality indicators}

It is often the observation of visible attributes that brings to attention the changes in soil quality and causes public awareness and, at times, alarm. But in many cases, when there is visible evidence of decline in soil quality, the process of decline may have proceeded too far, and the chance to restore quality may have already been lost. The visible attributes include evidence of erosion in the form of rills and gullies, exposure of subsoil, surface ponding of water, surface runoff, and poor plant growth (Stephen, 2002).

\section{NRM and Soil Quality Indicators}

\section{Changes in physical quality indicators}

The recent developments in soil quality research emphasise the importance of identifying key soil indicators and their threshold values in relation to specific soil functions. The potential of a soil to support crop growth is largely 
determined by the environment that the soil provides for root growth. Roots need air, water, nutrients and adequate space to develop and make water and nutrients accessible to plants.

Such physical attributes as bulk density, porosity, air-filled porosity, crusting, sealing, water-holding capacity and depth all determine how well roots develop. Changes in these physical soil attributes directly affect the health and productivity of crops. The influence of agricultural practices, specifically NRM interventions, on changes in some soil physical attributes / indicators are discussed in the following examples.

\section{Bulk density}

Compact soil layers with high bulk density in the soil profile impede root growth by reducing the effective soil rooting volume. Measurements of soil bulk density along with penetration resistance (interpreted with respect to water contents) are used to identify root-impeding layers in the soil profile. When the bulk density of a soil increases to a critical level, it impedes root penetration and restricts root growth and the soil volume explored by roots. For example, in many Alfisols in SAT regions, soil compaction is one of the major constraints to crop establishment and productivity (El-Swaify et al., 1985). Pierce et al. (1983) reported critical values of bulk density for soils varying in texture. Compaction by wheeled traffic has direct and at times irreversible effects on soil structure.

A long-term experiment conducted at the International Crops Research Institute for the Semi-Arid Tropics (ICRISAT), Patancheru, India examined the impact of improved management options on soil physical attributes (Table 3.2). It was found that management practices in Vertisol

Table 3.2. The effect of management practices on physical properties of Vertisols at ICRISAT, Patancheru, India (1975-99).

\begin{tabular}{|c|c|c|c|}
\hline \multirow[b]{2}{*}{ Soil properties } & \multicolumn{2}{|c|}{$\begin{array}{l}\text { Improved land } \\
\text { management technology }\end{array}$} & \multirow{2}{*}{$\begin{array}{c}\begin{array}{c}\text { Traditional } \\
\text { technology }\end{array} \\
\text { Flat }\end{array}$} \\
\hline & Broadbed & Furrow & \\
\hline \multicolumn{4}{|l|}{ 1. Texture $(0-10 \mathrm{~cm}$ soil layer $)$} \\
\hline Clay $(\%)$ & 50.8 & & 46.3 \\
\hline Silt $(\%)$ & 21.5 & & 21.4 \\
\hline Fine sand (\%) & 15.5 & & 15.4 \\
\hline Coarse sand (\%) & 12.2 & & 16.9 \\
\hline Gravel (\%) & 4.8 & & 14.5 \\
\hline 2. Bulk density $\left(\mathrm{g} / \mathrm{cm}^{3}\right)$ & 1.2 & 1.5 & 1.5 \\
\hline 3. Total porosity (\%) & 52.1 & 39.5 & 41.5 \\
\hline 4. Air-filled porosity (\%) & 41.0 & 33.0 & 32.0 \\
\hline 5. Penetration resistance (MPa) & 1.1 & 9.8 & 8.5 \\
\hline 6. Sorptivity $\left(\mathrm{mm} / \mathrm{h}^{1 / 2}\right)$ & 121.2 & 100.6 & 88.5 \\
\hline 7. Cumulative infiltration in $1 \mathrm{~h}(\mathrm{~mm})$ & 347.2 & 205.7 & 264.7 \\
\hline
\end{tabular}

Source: ICRISAT, experimental results 
watersheds caused significant differences in soil bulk densities. Throughout the soil profile, the bulk density was found to be significantly lower in the watershed with improved technology than in the watershed where a traditional system was used (Fig. 3.1).

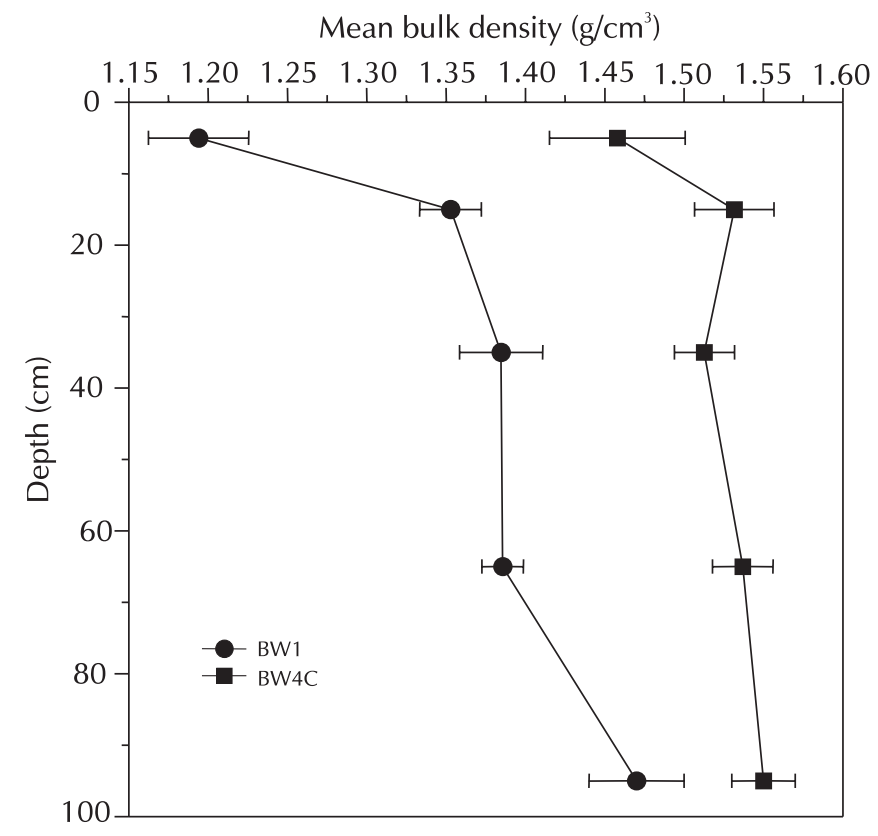

Fig. 3.1. Long-term effects of improved (BW1) and traditional (BW4C) management practices on bulk density of Vertisols, ICRISAT, Patancheru, India, 1975-98.

However, the differences in bulk densities were relatively greater in the top $15 \mathrm{~cm}$ layer. The maximum difference in bulk density was recorded in the $0-5 \mathrm{~cm}$ layer. The data clearly show the advantage of the improved technology where the soil is kept loose. This has major implications for root growth and tillage operations especially when tillage operations are done using animal power.

\section{Penetration resistance}

Penetration resistance measurement can be measured to identify rootimpeding layers. When the penetration resistance of a soil increases to a critical level, it becomes more difficult for roots to penetrate and their growth is impeded. The long-term ICRISAT experiment showed that the soil in a watershed where improved land and water management was practised had a lower penetration resistance in the cropping zone than the corresponding zone in one traditionally managed (Fig. 3.2). The penetration resistance however increased with depth, but it was consistently lower with improved management. In the long term the broadbed-and-furrow (BBF) land configuration in the improved system led to progressive improvement 
in soil tilth in the bed zone. The BBF land configuration and reduced penetration resistance allows timely tillage operations that are crucial for Vertisols because they are difficult work, both in dry and very wet conditions. Klaij (1983) reported similar results on the positive effects of land surface treatments for Alfisols where lower penetration resistance is crucial for crop emergence and root growth.

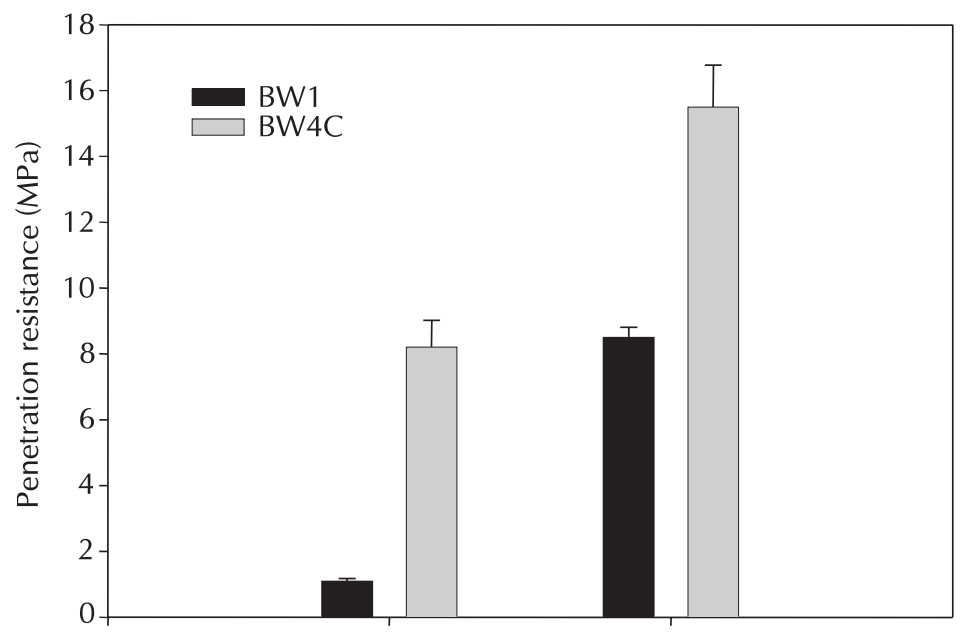

Fig. 3.2. Long-term effects of improved (BW1) and traditional (BW4C) management practices on soil penetration resistance of Vertisols, ICRISAT, Patancheru, India, 1975-98.

Porosity/air-filled porosity

The problem of temporary waterlogging and the resulting lack of adequate aeration is quite common in many soils. In medium to high rainfall areas, crops on Vertisols often suffer extensively from temporary waterlogging and poor soil aeration (El-Swaify et al., 1985). In such situations, maintaining high air-filled porosity is crucial to increasing crop productivity. A long-term experiment on Vertisols at ICRISAT showed the improved system had higher air-filled porosity than the traditional system(Fig.3.3). In theimproved system, the air-filled porosity in the top $10 \mathrm{~cm}$ layer improved by $28 \%$ during 197598. This improvement contributed to better crop growth and higher yields.

Rooting depth

Rooting depth is the depth in the soil profile to which roots penetrate and access water and plant nutrients. Rooting depth is especially important in dryland agriculture where the shortage of both water and nutrients limit plant growth and productivity. Exploration of large volumes of soil by roots can increase the accessibility of water and nutrients to growing plants. Deeprooted crops are considered better at extracting water and nutrients from 


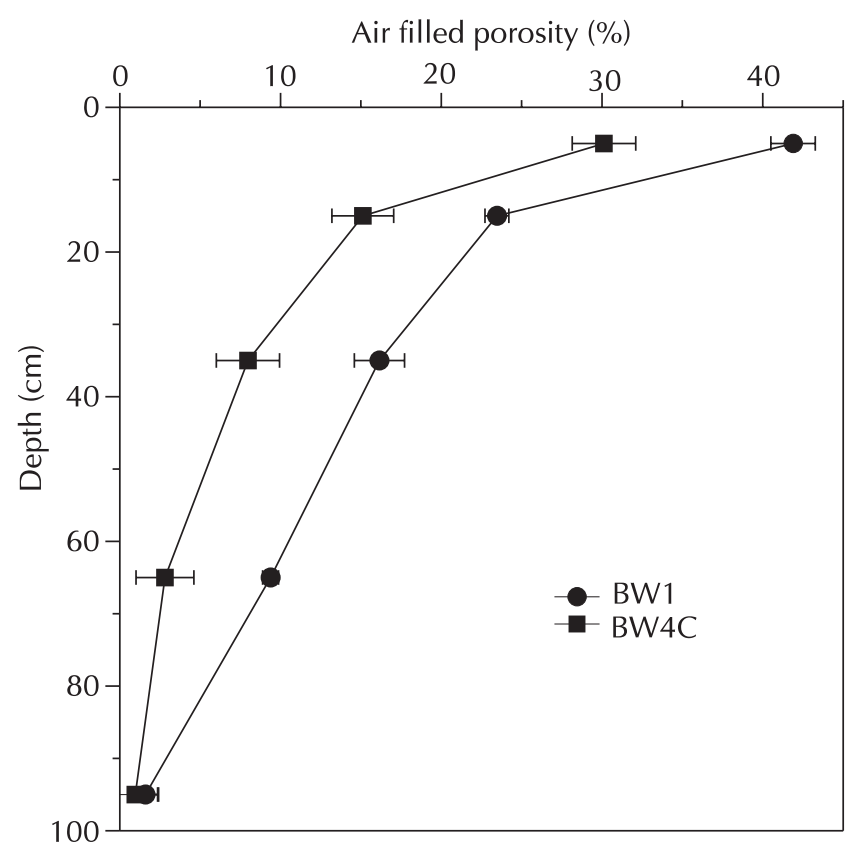

Fig. 3.3. Long-term effects of improved (BW1) and traditional (BW4C) management practices on air-filled porosity of Vertisols, ICRISAT, Patancheru, India, 1975-98.

deeper layers in the soil profile. Dryland crops such as sorghum may send their roots over $1 \mathrm{~m}$ deep into the soil in search of water (El-Swaify et al., 1985). Irrigated crops such as rice have relatively shallow rooting depths (up to $60 \mathrm{~cm}$ ). The threshold values for rooting depth vary with crop and the irrigated or non-irrigated conditions under which the crop is grown. The deeper rooting depths of dryland crops need to be considered while using indicators.

It is not surprising that rooting depth has been related to crop productivity. Crops grown in soils in which the rooting depth is limited by the presence of a physical or chemical constraint are generally less productive. As limiting layers move closer to the soil surface where erosion removes the topsoil, crop productivity generally declines. The effect of rooting depth on crop productivity varies with crop type (Taylor and Terrell, 1982). Soil management practices can have important effects on rooting depth. For example, erosion reduces rooting depth by removing the top soil layer while compaction reduces it by bringing to the surface layers in the soil that are impenetrable by crop roots (National Research Council, 1993). Changes in soil management practices influence root mass and length in the soil that are indicative of changes in rooting depth and can be monitored by sampling the roots at various depths in the profile.

\section{Water-holding capacity}

An important attribute of a soil is its ability to store and release water to growing plants. The water-holding capacity of soils is measured as the 
total amount of water stored in the different soil layers of a given profile. Plant-available water capacities of soils are required as inputs for nearly all crop simulation models. Water-holding capacity is directly related to soil structure and texture. The rate and direction of water flow through the soil is an important factor determining the effect of farming practices on soil quality (Sahrawat et al., Chapter 4, this volume).

Management of the soil can have significant effects on its water-holding capacity by changing the depth and texture of surface layers (through soil erosion), the structure and compactness of surface and subsurface layers, and by affecting the rate of infiltration of rainfall. Ritchie (1981) discussed the importance of water available to plants and the techniques for measuring plant-available water in soils. Plant-available water capacities are determined at the depth of rooting considering temporal changes in plant-available water capacities during the growing season. The water-holding capacity of soil is estimated by the difference in water content at field capacity and wilting point of soil. Both these parameters can be measured in the laboratory or field using methods described by Singh and Vittal (1997).

\section{Soil loss}

Soil erosion has an overriding influence on soil characteristics that determine soil quality for productivity and environment-related functions. Eroded sediments usually contain higher amounts of plant nutrients than do bulk soils, thus soil erosion depletes the soil of nitrogen $(\mathrm{N})$, phosphorus $(\mathrm{P})$, potassium $(\mathrm{K})$, and total organic carbon $(\mathrm{C})$ reserves (Barrows and Kilmer, 1963; Young et al., 1985; Lal, 2004). Erosion can also bring subsoil horizons closer to the surface of the soil profile. These horizons might have different $\mathrm{pH}$, low available water-holding capacities, and high bulk densities and can thus influence soil quality. For example using the productivity index model, Pierce et al. (1983) and Larson et al. (1985) determined which of the four soil attributes in the subsoil - available water-holding capacity, bulk density, $\mathrm{pH}$, or rooting depth - would cause the greatest decline in soil productivity on 75 major soils of the Corn Belt of the USA, assuming that erosion removed $50 \mathrm{~cm}$ (20 inches) of soil from the surface. Of the 75 soils tested, the productivity index decreased significantly in 37. This was associated with a significant degradation in the available water-holding capacity in the subsoil (13 soils), increased bulk density (4 soils), decreased rooting depth (7 soils), and increased bulk density combined with decreased rooting depth (13 soils) (Larson et al., 1985).

Soil erosion removes organic carbon along with sediments. Since organic carbon content is an important indicator of soil quality, it is suggested that current rates of erosion may have significant effects on long-term soil quality (National Research Council, 1993).

Soil loss can be measured using suitable sediment samplers (Pathak et al., 2002). Soil loss is commonly estimated using equations such as the Universal Soil Loss Equation (USLE) or the Water Erosion Prediction Project (WEPP) model. These models require data on soil properties, slope, erosion control practices in use, vegetative cover, rainfall and other climatic parameters. 
The effects of management practices on soil loss can also be measured using field experiments. For example, El-Swaify et al. (1985) reported a long-term watershed experiment on Vertisols at ICRISAT, Patancheru, soil loss from erosion from watersheds under improved and traditional systems (Table 3.3).

The annual soil loss gives a good indication of the long-term effect of soil erosion on the productive capacity of soils. It is also useful in determining off-site sediment damages and the effectiveness of conservation technologies. The changes in soil physical quality indicators reported in Table 3.2 took place only in the long term. They might have been partly due to a differential loss of soil under improved and traditional management practices (Table 3.3).

Table 3.3. The effect of management practices on runoff and soil loss in watersheds at ICRISAT, Patancheru, India 1974-82.

\begin{tabular}{|c|c|c|c|c|c|c|}
\hline \multirow[b]{2}{*}{ Year } & \multicolumn{3}{|c|}{ Improved } & \multicolumn{3}{|c|}{ Traditional } \\
\hline & $\begin{array}{c}\text { Rainfall } \\
(\mathrm{mm})\end{array}$ & $\begin{array}{c}\text { Runoff } \\
\text { (\% of seasonal } \\
\text { rainfall) }\end{array}$ & $\begin{array}{l}\text { Soil loss } \\
\text { (t/ha) }\end{array}$ & $\begin{array}{c}\text { Rainfall } \\
(\mathrm{mm})\end{array}$ & $\begin{array}{c}\text { Runoff } \\
\text { (\% of seasonal } \\
\text { rainfall) }\end{array}$ & $\begin{array}{l}\text { Soil loss } \\
\text { (t/ha) }\end{array}$ \\
\hline 1974 & 811 & 14.3 & 1.30 & 811 & 27.5 & 6.60 \\
\hline 1975 & 1041 & 15.6 & 1.39 & 1055 & 24.0 & 5.21 \\
\hline 1976 & 687 & 10.6 & 0.98 & 710 & 33.3 & 9.20 \\
\hline 1977 & 585 & 0.2 & 0.07 & 586 & 9.0 & 1.68 \\
\hline 1978 & 1125 & 24.3 & 2.93 & 1117 & 36.7 & 9.69 \\
\hline 1979 & 690 & 10.6 & 0.70 & 682 & 29.6 & 9.47 \\
\hline 1980 & 730 & 15.9 & 0.97 & 688 & 24.1 & 4.58 \\
\hline 1981 & 1126 & 29.5 & 5.04 & 1126 & 38.6 & 11.01 \\
\hline 1982 & 615 & 1.6 & 0.20 & 615 & 3.3 & 0.70 \\
\hline Mean & 823 & 13.6 & 1.51 & 821 & 25.1 & 6.46 \\
\hline
\end{tabular}

Source: Adapted from El-Swaify et al., 1985

\section{Changes in chemical quality indicators}

The objective of using appropriate chemical indicators is to sustain agricultural productivity without adversely affecting soil quality. Chemical quality indicators used to monitor soil quality include organic matter, cation exchange capacity (CEC), soil acidity and exchangeable bases, soil salinity and sodicity, total and available $\mathrm{P}$, total exchangeable and non-exchangeable $\mathrm{K}$, total and available sulphur (S) and soil reserves of total and available micronutrients (Table 3.1).

In the following section, examples are given of the use of some chemical indicators for monitoring soil quality in crop production systems.

\section{Organic carbon}

Organic matter is an important component of soil and consists of organic C and total N. Generally, organic C constitutes $58 \%$ of soil organic matter, and is used as a measure of when to convert organic $C$ to organic matter in soils. 
Organic matter plays a critical role in maintaining physical, chemical and biological integrity of soils. Total organic $\mathrm{C}$ is measured using wet digestion or combustion methods in the laboratory. The dynamics of soil organic matter are controlled by management practices and agroclimatic factors, especially rainfall, temperature and soil-water regime. The maintenance of organicmatter status in soils, especially in arable production systems in tropical regions, is a challenge. In contrast, it is relatively easy to maintain organic matter levels in wetland rice soils because compared to arable systems, organic matter preferentially accumulates in soils under wetland paddy culture (Jenny and Raychaudhari, 1960; Sahrawat, 2004). Although the decomposition of organic matter is fast in tropical conditions, the primary productivity of wetlands is much higher than that of arable soils; this, combined with several other factors, results in a preferential accumulation of organic matter in wetlands (see Sahrawat, 2004).

Soil organic C influences the physical, chemical and biological characteristics of soil which directly or indirectly influence crop productivity. Compared to soils in the temperate or humid tropics, soils in SAT regions have relatively low contents of soil organic matter. The traditional farming practices followed by farmers in the dryland areas do not maintain sufficient soil organic matter content (El-Swaify et al., 1985). The changes in soil organic $\mathrm{C}$ that can be measured accurately take a long time to occur, and depend on the determination methods used and their precision. However, the changes in soil organic $\mathrm{C}$ can be an important soil quality indicator for evaluating the impact of management practices in both agricultural and forest lands.

The long-term effects of improved and traditional management on soil chemical and biological properties of Vertisols are shown in Table 3.4. Soil organic $\mathrm{C}$, total $\mathrm{N}$ and available $\mathrm{N}, \mathrm{P}$, and $\mathrm{K}$, microbial biomass $\mathrm{C}$ and $\mathrm{N}$ were higher in the improved than in the traditional system (Wani et al., 2003).

\section{Total nitrogen}

Like organic matter, total $\mathrm{N}$ is an important indicator for soil chemical quality. Total $\mathrm{N}$ with organic $\mathrm{C}$ constitutes soil organic matter. Total $\mathrm{N}$ consists of organic and inorganic $\mathrm{N}$; organic $\mathrm{N}$ is the source of $\mathrm{N}$ supply to growing plants. Total soil $\mathrm{N}$ is commonly measured in the laboratory using digestion but combustion methods can also be used for its determination.

A long-term (1985-97) experiment on a Vertisol at ICRISAT studied the effects of introducing different legumes into cropping systems and their rotation to improve system productivity through the supply of $\mathrm{N}$ by legumes. The total soil $\mathrm{N}$ concentration in the $0-15 \mathrm{~cm}$ layer increased by 125 $\mu \mathrm{g} \mathrm{N} / \mathrm{g}$ of soil in 12 years in pigeonpea-based systems that had no input of N (Rego and Rao, 2000). In the traditional (rainy-season fallow, postrainyseason sorghum) and non-legume based system, the total soil $\mathrm{N}$ declined compared to the baseline.

Cereal- $\mathrm{N}$ requirements are large and an increase in $\mathrm{N}$ use efficiency is highly desirable, not only for economic considerations, but improved Nuse efficiency also reduces chances of surface and groundwater resources 
Table 3.4. Biological and chemical properties of semi-arid tropical Vertisols in 1998 after 24 years of cropping under improved and traditional systems in catchments at ICRISAT, Patancheru, India.

\begin{tabular}{|c|c|c|c|c|}
\hline \multirow[b]{2}{*}{ Properties } & \multirow[b]{2}{*}{ System } & \multicolumn{2}{|c|}{ Soil depth $(\mathrm{cm})$} & \multirow{2}{*}{$\begin{array}{c}\text { Standard } \\
\text { error }\end{array}$} \\
\hline & & $0-60$ & $60-120$ & \\
\hline \multirow[t]{2}{*}{ Organic carbon (t C/ha) } & Improved & 27.4 & 19.4 & \multirow[t]{2}{*}{0.89} \\
\hline & Traditional & 21.4 & 18.1 & \\
\hline \multirow[t]{2}{*}{ Soil respiration (kg C/ha) } & Improved & 723 & 342 & \multirow[t]{2}{*}{7.8} \\
\hline & Traditional & 260 & 98 & \\
\hline \multirow[t]{2}{*}{ Microbial biomass C (kg C/ha) } & Improved & 2676 & 2137 & \multirow[t]{2}{*}{48.0} \\
\hline & Traditional & 1462 & 1088 & \\
\hline \multirow[t]{2}{*}{ Microbial biomass $\mathrm{N}$ (kg N/ha) } & Improved & 86.4 & 39.2 & \multirow[t]{2}{*}{2.3} \\
\hline & Traditional & 42.1 & 25.8 & \\
\hline \multirow[t]{2}{*}{ Non-microbial organic $\mathrm{N}$ (kg N/ha) } & Improved & 2569 & 1879 & \multirow[t]{2}{*}{156.9} \\
\hline & Traditional & 2218 & 1832 & \\
\hline \multirow[t]{2}{*}{ Total N (kg N/ha) } & Improved & 2684 & 1928 & \multirow[t]{2}{*}{156.6} \\
\hline & Traditional & 2276 & 1884 & \\
\hline \multirow[t]{2}{*}{ Mineral N (kg N/ha) } & Improved & 28.2 & 10.3 & \multirow[t]{2}{*}{2.88} \\
\hline & Traditional & 15.4 & 26.0 & \\
\hline \multirow[t]{2}{*}{ Net $\mathrm{N}$ mineralisation (kg N/ha) } & Improved & -3.3 & -6.3 & \multirow[t]{2}{*}{4.22} \\
\hline & Traditional & 32.6 & 15.4 & \\
\hline \multirow[t]{2}{*}{ Olsen P (kg P/ha) } & Improved & 6.1 & 1.6 & \multirow[t]{2}{*}{0.36} \\
\hline & Traditional & 1.5 & 1.0 & \\
\hline
\end{tabular}

Source: Wani et al., 2003

pollution with N (Sahrawat et al., Chapter 4, this volume). Hence, N-use efficiency should be considered an important soil and water quality indicator for monitoring the biophysical impacts of NRM.

\section{Changes in available soil nutrient reserves}

In addition to the use of organic $\mathrm{C}$ and $\mathrm{N}$ as chemical quality indicators, several other soil attributes are used for soil quality for agricultural and environment-related functions. These include changes in CEC and total and extractable nutrient status with regard to major (N, P, and $\mathrm{K}$ ), secondary (calcium (Ca), magnesium (Mg), and sulphur (S)) and micronutrients (iron $(\mathrm{Fe})$, zinc $(\mathrm{Zn})$, manganese $(\mathrm{Mn})$, boron $(\mathrm{B})$, and molybdenum $(\mathrm{Mo})$ ).

Nutrient balances in production-systems can also be effectively used to ascertain the sustainability of the systems. Soils have a nutrient reserve controlled by their inherent fertility and management. A negative balance of such nutrients as $\mathrm{N}, \mathrm{P}$ and $\mathrm{K}$ indicates nutrient mining and non-sustainability of the production systems. 


\section{Diffuse reflectance spectroscopy}

Assessments of soil attributes normally rely on laboratory data resulting from the analysis of large numbers of samples required to adequately characterise spatial variability beyond the plot scale. Methods for rapid estimation of soil properties are needed for quantitative assessment of soil quality parameters. Shepherd and Walsh (2002) developed a promising approach that estimates several soil properties simultaneously, directly from diffuse reflectance spectra in rapid non-destructive ways. The method is based on scanning airdried samples using a portable spectrometer $(0.35-2.5 \mu \mathrm{m}$ wavelength) with an artificial light source. Soil properties are calibrated to reflectance using multivariate adaptive regression splines and screening tests are developed for various soil fertility constraints using classification trees. At random, onethird of the soil samples are used for validation purposes (using standard and the proposed methods). Using this technique from about 3000 African soils belonging to nine orders, Shepherd and Walsh found that the soil attributes could be calibrated directly to soil reflectance spectra with validation $\mathrm{R}^{2}$ values ranging from 0.70 to 0.88 , indicating good agreement between the values obtained by their proposed method and standard laboratory methods. The soil attributes calibrated included: exchangeable $\mathrm{Ca}$; effective cationexchange capacity (ECEC); exchangeable $\mathrm{Mg}$; organic $\mathrm{C}$ concentration; clay content; sand content and soil $\mathrm{pH}$.

The spectral technique provides a tool for generating results of soil assessments that are conducted at a limited number of sites and thereby increase the efficiency of expensive and time-consuming soil-related studies. The rapid nature of the measurement allows soil variability to be more adequately sampled than by the conventional approach.

The spectral library approach of Shepherd and Walsh (2002) provides a coherent framework for linking soil information with remote sensing information for improved spatial prediction of soil functional capacity for agricultural, environmental, and engineering applications. Indeed, as shown below, Sanchez et al. (2003) found this approach useful for fertility capability classification (FCC) when assessing soil quality.

\section{Changes in biological quality indicators}

The dynamic nature of soil microorganisms makes them sensitive indicators of the soil processes leading to changes in soil quality. Biological indicators based on microbial composition, number and processes provide advanced indication of subtle changes in soil quality. However, changes in soil physical and chemical properties alter the soil environment that supports the growth of the microbial population (Lee and Pankhurst, 1992; Stott et al., 1999).

\section{Total number of microorganisms}

Total microbial counts can be used as a good indicator to assess the impact of a particular management treatment on soil biological activity. The microbial population is enumerated by microscopy. Microorganisms are extracted from 
soil and transferred to an optically suitable background before enumeration. Several studies have recorded increase in microbial numbers in soils soon after adding an available C source (Jenkinson and Ladd, 1981).

\section{Soil respiration}

Soil respiration is the oxidation of organic materials by soil microorganisms that generates energy for microbial growth and maintenance, and produces carbon dioxide $\left(\mathrm{CO}_{2}\right)$. The soil respiration rate provides a comprehensive picture of total soil biological activity. Soil respiration is measured by determining the amount of $\mathrm{CO}_{2}$ evolved under well-defined conditions during a given time period. Soil respiration rates were found to be higher in Vertisols under an improved than in a traditionally managed system (Table 3.4).

\section{Microbial biomass carbon (C) and nitrogen (N)}

Microbial biomass $\mathrm{C}$ and $\mathrm{N}$ in soils represent a readily available source of plant nutrients. Because the decay and turnover of microbial biomass in soils is rapid it results in the release of $\mathrm{CO}_{2}-\mathrm{C}$ and available $\mathrm{N}$. Thus, measurement of microbial biomass $\mathrm{C}$ and $\mathrm{N}$ provide a dynamic indicator of soil quality which by accurate standardisation can also be used to measure the extent of soil degradation. Microbial biomass $\mathrm{C}$ and $\mathrm{N}$ are measured as the net release of $\mathrm{C}$ and mineral $\mathrm{N}$ (ammonium plus nitrate) that results from fumigation of soil samples (Jenkinson and Ladd, 1981).

Soil and water conservation, tillage, and cropping systems influence microbial biomass $\mathrm{C}$ and $\mathrm{N}$ (Table 3.4). It has been suggested that soils with a higher proportion of soil organic $C$ as microbial biomass gain $C$; those with a lower proportion lose C (Anderson and Domsch, 1986).

In a long-term (24-years) experiment on Vertisols, microbial biomass $C$ was about $10.3 \%$ of the total soil organic $C$ in the improved system compared to only $6.4 \%$ in the traditional system. Improved Vertisols management practices resulted in higher values (10.3 vs. $6.4 \%)$ of biomass $C$ as a proportion of soil organic $C$ to $120-\mathrm{cm}$ soil depth, indicating that with improved management these Vertisols would reach a new C-storage equilibrium. The microbial $\mathrm{N}$ was $2.6 \%$ of the total biomass $\mathrm{N}$ in the improved system and $1.6 \%$ in the traditional system (Wani et al., 2003).

\section{Potentially mineralisable nitrogen}

Along with microbial biomass $\mathrm{N}$, potentially mineralisable $\mathrm{N}$ serves as a surrogate for the 'active $\mathrm{N}$ fraction' for soil quality impact assessment. The measurement of potentially mineralisable $\mathrm{N}$ in soils is based on the net release of mineral $\mathrm{N}$ (ammonium plus nitrate) from soil samples incubated for a given period under well-defined moisture and temperature conditions. Cropping systems and inputs of organic matter affect potentially mineralisable N (Wani et al., 1994).

\section{Earthworm activity}

Changes in earthworm populations can significantly affect soils by influencing soil structure, nutrient cycling dynamics, and soil microbial populations. 
The earthworm population decreases as soil degradation increases, and this can serve as a very sensitive indicator of soil degradation (Tian et al., 2000). The earthworm population can be measured by earthworm counts per soil volume (e.g. number $/ \mathrm{m}^{3}$ of soil) in the cultivated layer.

\section{Integrated Soil Quality Indicators}

Whilst there may be doubts about the efficacy of developing integrated indices of soil quality, there is a continuing demand for them, given the complex nature of the soil and the exceptionally large number of soil properties that need to be determined. At the Rodale International Conference on the Assessment and Monitoring of Soil Quality, there was a general consensus that soil quality (Rodale Institute, 1991, cited in Arshad and Martin, 2002) encompasses three broad issues:

1. The ability of the soil to enhance crop production (productivity component)

2. The ability of the soil to function in attenuation of environmental contaminants, pathogens, and off-site damage (environment component)

3. The linkage between soil quality and plant, animal and human health (health component).

It has, therefore, been suggested that any protocol designed to determine soil quality must provide an assessment of the function of soil with regard to these three issues. To do this effectively, soil quality assessment must incorporate specific performance criteria for each of the three elements listed above, and it must be structured in such a way as to allow for quantitative evaluation and unambiguous interpretation using one aggregate soil quality index (that incorporates the above three soil functions). The objective of the proposed approach is in defining a single integrated soil quality index and not to replace past research on specific indicators but to complement it by presenting a more clearly defined framework for the development of mathematical relationships driven by basic soil attributes (Doran and Parkin, 1994).

\section{Soil quality indices}

Since soil quality encompasses plant and biological productivity, environmental quality, and human and animal health, it is imperative that the soil quality indicator provides an assessment of these functions. To achieve this objective effectively, the soil quality indicator must incorporate specific performance criteria for each function. This concept gave birth to an index.

Parr et al. (1992) proposed a soil quality index (SQ) as follows:

$$
S Q=f(S P, Q, E, H, E R, B D, F Q, M I)
$$

where $S P$ are the soil properties, $Q$ the potential productivity, $E$ the environmental factors, $H$ the health (human/animal), ER the erodibility, $B D$ the biological diversity, $F Q$ the food quality/safety, and $M I$ the management inputs. 
There has been some effort to define the exact mathematical form of the generic functional form given in Equation 1. Subsequent to the Rodale Conference, many soil scientists have proposed more detailed procedures for evaluating soil quality functions by combining and integrating specific soil quality elements into soil quality indices (Doran and Parkin, 1994; Karlen and Stott, 1994). These procedures allow for weighting of various soil quality elements, depending upon the user goals, site-specific considerations and socio-economic concerns. For example, Doran and Parkin (1994) proposed the following index of soil quality as a function of six specific soil quality elements:

$$
S Q=f\left(S Q_{E 1^{\prime}} S Q_{E 2^{\prime}} S Q_{E 3^{\prime}} S Q_{E 4^{\prime}} S Q_{E 5^{\prime}} S Q_{E 6}\right)
$$

where the specific soil quality elements $\left(S_{\mathrm{E}}\right)$ are defined as:

$S Q_{E 1}=$ food and fibre production

$S Q_{E 2}=$ erosivity

$S Q_{E 3}=$ groundwater quality

$S Q_{E 4}=$ surface water quality

$S Q_{E 5}=$ air quality

$S Q_{E 6}=$ food quality

The advantage of this approach is that the different functions of soil can be assessed by specific performance criteria established for each element for a given ecosystem: for example, yield goals for crop production $\left(S Q_{E 1}\right)$; limits for erosion losses $\left(S Q_{E 2}\right)$; concentration limits for chemical leaching from the rooting zone $\left(S Q_{E 3}\right)$; nutrient, chemical, and sediment loading limits to adjacent surface water systems $\left(S Q_{E 4}\right)$; production and uptake rates for trace gases that contribute to ozone $\left(\mathrm{O}_{3}\right)$ destruction or the greenhouse effect $\left(S Q_{E 5}\right)$; and nutritional composition and chemical residue of food $\left(S Q_{E 6}\right)$.

One suggestion to operationalise this aggregate index is to use a weighted simple multiplicative function:

$$
S Q=\left(K_{1} S Q_{E 1}\right)\left(K_{2} S Q_{E 2}\right)\left(K_{3} S Q_{E 3}\right)\left(K_{4} S Q_{E 4}\right)\left(K_{5} S Q_{E 5}\right)\left(K_{6} S Q_{E 6}\right)
$$

where $K_{i}=$ weighting coefficients for the different soil quality parameters.

There could be several ways to develop an aggregate index from a set of different soil quality indicators. Campbell et al. (2003) propose various approaches including simple additive indices, principal components methods, canonical correlations and simple radar diagrams for evaluating the performance of NRM interventions. For example, to develop a simple additive index, it is necessary to know the maximum and minimum values of each indicator. A standardised value for each indicator is then calculated using the formula: (Indicator value at time $x$ - minimum) / (maximum - minimum). For each indicator the potential values range from 0 (least desirable) to 1 (most desirable). A composite index is then calculated as the average of the indicator values. Weights can also be added if the relative importance of the different performance indicators is known. Details of the advantages and disadvantages of the other approaches can be found in Campbell et al. (2003). 
Although the proposed indices would seem promising since they integrate several soil attributes in a single index, there are no published reports on their practical application and evaluation in the field. If this approach is going to be useful for NRM impact assessment, further research on the different ways of developing a comprehensive indicator would need to be carried out. When multiple variables are measured to characterise soil quality, it may not be easy to reduce the various indicators into a single and meaningful index.

\section{Fertility capability classification (FCC) approach}

Sanchez et al. (2003) stated that the soil quality paradigm that was originally developed in the temperate region is not very suitable for the tropics. According to them, soil quality in the tropics should focus on three main concerns: food insecurity, rural poverty and ecosystem degradation. Soil quality in the tropics must be considered a component of the integrated natural resources management (INRM) framework, therefore Sanchez et al. (2003) suggested that based on quantitative topsoil attributes and soil taxonomy, the fertility capability soil classification (FCC) system is probably a good starting point for measuring soil quality in the tropics. To overcome certain limitations, they proposed a new FCC version 4 (Sanchez et al., 2003).

The proposed system consists of two categories. The first - type/ substrata - describes topsoil and subsoil texture. The second - condition modifier - consists of 17 modifiers defined to delimit specific soil conditions affecting plant growth with quantitative limits. The type/substrata types and condition constitute soil attribute modifiers in terms of their capability for plant growth. The 17 condition modifiers include: soil drought stress (dry); nutrient capital reserves; erosion risk; aluminium toxicity; major chemical limitations; P fixation; waterlogging; leaching potential; calcareous reaction; cracking clays; gravel; shallow depth; salinity; alkalinity; presence of amorphous materials; volcanic soils; high organic content; and sulphidic soils. Like other soil indices, the FCC approach can be used to evaluate and monitor soil quality for soil productivity and sustainability purposes by measuring the FCC index at regular intervals starting with baseline measurement.

There are several important issues not addressed by this new version of FCC. These include nutrient depletion, soil compaction, surface sealing, surface crusting and others related to air and water flow. The FCC-based soil index is still at an initial stage and many more details still need to be worked out before it can be used.

\section{Models to Assess Soil Quality}

The development of relationships between soil attributes and the functions of soils is a monumental task. Simulation models can be useful tools in tracking and understanding these relationships. Algorithms in existing simulation models [e.g. the Nitrate Leaching and Economic Analysis Package (NLEAP), 
Erosion-Productivity Impact Calculator (EPIC), Chemical, Runoff and Erosion from Agricultural Management Systems (CREAMS), and Water Erosion Prediction Project (WEPP)] may provide a useful starting point (Doran and Parkin, 1994). These models provide a predictive tool for the process such that, given what is known, if one of the parameters that affect the process changes, the associated change in a given indicator can be predicted (Arshad and Martin, 2002). Models are normally constructed using results of detailed long-term data. Because agroclimatic conditions often vary from year to year, reliable long-term data is essential to capture the historical reality and predict future events with some degree of confidence. By using soil process models, the rate of change and the direction of change in selected soil quality indicators can be predicted. Models allow the researcher to simulate various management practices in order to predict their consequences and impacts on biophysical soil conditions and on such economic outputs as grain yield. Wani et al. (Chapter 5, this volume) discuss the use of simulation modelling to predict the likely impacts of NRM on various soil quality indicators.

One of the major limitations in using these models is that most of them require calibration and testing before they can be used in a given region. To the extent that the impacts of NRM interventions tend to be location-specific, lack of data from a given location can become a major limiting factor in validating the models to local conditions.

\section{Summary and Conclusions}

The intensification of agricultural activities to meet the increasing demands from fast-growing populations, particularly in the developing countries, without sufficient investments to sustain the system has led to rapid soil degradation. There is also increasing conflict among the various agricultural and environmental functions of soils. Various NRM interventions have been designed to counter the process of degradation or to enhance the sustainability of the system. In order to enhance the effectiveness of these interventions, and to attain the desired objectives, suitable indicators are required to monitor the biophysical impacts of management practices on soil conditions. This calls for the development of threshold levels for the various indicators, as these values are likely to vary by ecoregion and soil type.

In practical terms, it is not feasible to recommend the use of a large number or a common set of indicators for all agricultural interventions because of the varying size and complexity of agricultural and watershed development projects. Therefore, the selection of a few relevant indicators based on the purpose and an adequate understanding of various processes at the local level is extremely important. However, there is a general consensus that any assessment of soil quality must include a minimum set of physical, chemical and biological soil parameters. In this context the importance of a baseline characterisation of soils and sites to measure the changes attributable to a given management intervention cannot be overemphasised. 
Review of the available literature and empirical examples has indicated that in general, biological indicators, followed by chemical and physical indicators could be successfully used to monitor theimpact of soil management options. Changes in such physical indicators as texture, infiltration, moisture holding capacity, bulk density, porosity, aggregate stability, surface crusting and sealing, soil compaction and penetration resistance take considerable time. However, depending on the magnitude of the change, simple physical measurements such as runoff and soil loss can serve as supplementary indicators of changes in soil quality. Such soil chemical indicators as $\mathrm{pH}$, salinity, organic $\mathrm{C}$, organic matter content, CEC, status of plant nutrients, and concentration of potentially toxic elements can also provide good indicators. Changes in soil organic $\mathrm{C}, \mathrm{CEC}$, or soil $\mathrm{pH}$ or the build up of toxic elements require a long time span and cannot be monitored during a short NRM intervention. Amongst the biological indicators soil respiration, microbial biomass $\mathrm{C}$ and $\mathrm{N}$ mineralisation are commonly used to monitor changes in soil quality.

Recently, Lal (2004) reviewed the progress made in identifying soil quality indicators, especially those that are relevant to the developing countries. The key soil quality indicators listed in Table 3.5 have been proposed and evaluated for universally monitoring soil quality, although the rate of change in these parameters and threshold values varies between soils in tropical (mostly developing) and temperate (mostly industrialised) countries (Lal, 2004). Obviously, since the purpose of NRM interventions is to enhance or sustain productivity, there is a need to relate the soil quality indicators to agricultural productivity and sustainability indicators.

Table 3.5. Recent developments in identifying physical, chemical and biological indicators of soil quality.

\begin{tabular}{ll}
\hline Indicator & Associated soil characteristics/properties \\
\hline Minimum data set & $\begin{array}{l}\text { Aggregate stability, clay content, bulk density, soil organic C } \\
\text { content, } \mathrm{pH}, \text { total } \mathrm{N}, \text { available } \mathrm{P}, \mathrm{S}, \text { micronutrients, mineralisable N } \\
\text { and microbial biomass } \mathrm{C} \text { and } \mathrm{N}\end{array}$ \\
Soil N & $\mathrm{N}$ use efficiency and INM (integrated nutrient management) \\
Soil P & Environmental threshold levels of soil P \\
Soil K & Threshold K values, positive K balance \\
Cations and acidity & Critical pH and cations (K, Ca, Mg and Na), Al and Mn toxicity \\
Soil organic matter status & Key indicator of soil quality and environment moderation \\
Subsoil compaction & Soil strength \\
Soil structure & Critical values of soil organic C concentration \\
Erosion & Soil organic C, effective rooting depth, available water capacity \\
Soil biological quality & Microbial biomass and activity, earthworm and termite biomass \\
\hline
\end{tabular}

Source: Adapted from Lal (2004) 
In the tropics lack of sufficient data often impedes a full assessment of the overall impact of NRM interventions on soil quality. Recently the use of an FCC, based on topsoil quantitative attributes and soil taxonomy, has been proposed. Version 4 of the FCC provides an alternative to qualitative approaches for assessing soil quality. Moreover, the development of such new tools as reflectance spectroscopy to predict soil functional attributes provides techniques for rapid measurement of soil characteristics. Simulation modelling and geographic information systems (GIS) can be useful tools for assessing the impact of NRM interventions on soil quality and the trade-offs between returns and environmental quality, especially when long-term and costly experimentation is not feasible.

\section{References}

Anderson, T.H. and Domsch, K.H. (1986) Carbon link between microbial biomass and soil organic matter. In: Megusar, F. and Gantar, M. (eds) Proceedings of Fourth International Symposium on Microbial Ecology, 24-29 August 1986, Ljubljana, Yugoslavia. Slovene Society for Microbiology, pp. 467-471.

Arshad, M.A. and Coen, G.M. (1992) Characterization of soil quality: physical and chemical criteria. American Journal of Alternative Agriculture 7, 5-12.

Arshad, M.A. and Martin, S. (2002) Identifying critical limits for soil quality indicators in agro-ecosystems. Agriculture, Ecosystems and Environment 88, 153-160.

Barrows, H.L. and Kilmer, V.J. (1963) Plant nutrient losses from soils by water erosion. Advances in Agronomy 15, 303-316.

Campbell, B.M., Sayer, J.A., Frost, P., Vermeulen, S., Perez, M.R., Cunningham, A. and Prabhu, R. (2003) Assessing the performance of natural resource systems. In: Campbell, B.M. and Sayer, J.A. (eds) Integrated Natural Resource Management: Linking Productivity, the Environment and Development. CAB International, Wallingford, UK, pp. 267-292.

Doran, J.W. and Parkin, T.B. (1994) Defining and assessing soil quality. In: Doran, J.W., Coleman, D.C., Bezdicek, D.F. and Stewart, B.A. (eds) Defining Soil Quality for a Sustainable Environment. Soil Science Society of America (Special Publication 35), pp. 3-21.

El-Swaify, S.A., Pathak, P., Rego, T.J. and Singh, S. (1985) Soil management for optimized productivity under rainfed conditions in the semi-arid tropics. Advances in Soil Science 1, 1-63.

Jenkinson, D.S. and Ladd, J.N. (1981) Microbial biomass in soil: measurement and turnover. In: Paul, E.A. and Ladd, J.N. (eds) Soil Biochemistry, Vol. 5. Marcel Dekker, New York, pp. 415-471.

Jenny, H. and Raychaudhari, S.P. (1960) Effect of Climate and Cultivation on Nitrogen and Organic Matter Reserves in Indian Soils. Indian Council of Agricultural Research, New Delhi, India, 127 pp.

Karlen, D.L. and Stott, D.E. (1994) A framework for evaluating physical and chemical indicators of soil quality. In: Doran, J.W., Coleman, D.C., Bezdicek, D.F. and Stewart, B.A. (eds) Defining Soil Quality for a Sustainable Environment. Soil Science Society of America (Special Publication 35), pp. 53-72.

Karlen, D.L., Mausbach, M.J., Doran, J.W., Cline, R.G., Harris, R.F. and Schuman, G.E. (1997) Soil quality: a concept, definition and framework for evaluation. Soil Science Society of America Journal 61, 4-10. 
Karlen, D.L., Ditzler, C.A. and Andrews, S.S. (2003) Soil quality: why and how? Geoderma 114, 145-156.

Klaij, M.C. (1983) Analysis and evaluation of tillage on Alfisol in a semi-arid tropical region of India. Ph.D. Thesis, University of Wageningen, Wageningen, The Netherlands, 178 pp.

Lal, R. (2004) Soil quality indicators in industrialized and developing countries similarities and differences. In: Schjønning, P., Elmholt, S. and Christensen, B.T (eds) Managing Soil Quality: Challenges in Modern Agriculture. CAB International, Wallingford, UK, pp. 297-313.

Larson, W.E., Pierce, F.J. and Dowdy, R.H. (1985) Loss in long-term productivity from soil erosion in the United States. In: El-Swaify, S.A., Moldenhauer, W.C. and Lo, A. (eds) Soil Erosion and Conservation. Soil Conservation Society of America, Ankeny, Iowa, pp. 262-217.

Lee, K.E. and Pankhurst, C.E. (1992) Soil organisms and sustainable productivity. Australian Journal of Soil Research 30, 855-892.

Letey, J., Sojka, R.E., Upchurch, D.R., Cassel, D.K., Olsen, K.R., Payne, W.A., Petrie, S.E., Price, G.H., Reginato, R.J., Scott, H.D., Smethurst, P.J. and Triplett, G.B. (2003) Deficiencies in the soil quality concept and its application. Journal of Soil and Water Conservation 58, 180-187.

National Research Council (United States) Committee on Long-Range Soil and Water Conservation Board on Agriculture (1993) Soil and Water Quality: an Agenda for Agriculture. National Academy Press, Washington, DC, 516 pp.

Parr, J.F., Papendick, R.I., Hornick, S.B. and Meyer, R.E. (1992) Soil quality: attributes and relationship to alternative and sustainable agriculture. American Journal of Alternative Agriculture 7, 5-10.

Pathak, P., Wani, S.P., Singh, P., Sudi, R. and Srinivasa Rao, Ch. (2002) Hydrological Characterization of Benchmark Agricultural Watersheds in India, Thailand, and Vietnam. Global Theme 3. Report no. 2. International Crops Research Institute for the Semi-Arid Tropics, Patancheru, India, $52 \mathrm{pp}$.

Pierce, F.J., Larson, W.E., Dowdy, R.H. and Graham, A.P. (1983) Productivity of soils: Assessing long-term changes due to erosion. Journal of Soil and Water Conservation $38,39-44$.

Rego, T.J. and Rao, V.N. (2000) Long-term effects of grain legumes on rainy-season sorghum productivity in a semi-arid tropical Vertisol. Experimental Agriculture 36, 205-221.

Ritchie, J.T. (1981) Soil water availability. Plant and Soil 58, 327-338.

Sahrawat, K.L. (2004) Organic matter accumulation in submerged soils. Advances in Agronomy 81, 169-201.

Sanchez, P.A., Palm, C.A. and Buol, S.W. (2003) Fertility capability soil classification: a tool to help assess soil quality in the tropics. Geoderma 114, 157-185.

Shepherd, K.D. and Walsh, M.G. (2002) Development of reflectance spectral libraries for characterization of soil properties. Soil Science Society of America Journal 66, 988-998.

Singh, P. and Vittal, K.P.R. (1997) Soil moisture measurement. In: Laryea, K.B., Pathak, P. and Katyal, J.C. (eds) Measuring Soil Processes in Agricultural Research. Technical Manual no. 3. International Crops Research Institute for the Semi-Arid Tropics (ICRISAT), Patancheru, India, pp. 65-82.

Sojka, R.E., Upchurch, D.R. and Borlaug, N.E. (2003) Quality soil management or soil quality management: performance versus semantics. Advances in Agronomy 79, $1-68$.

Steer, A. (1998) Making development sustainable. Advances in Geoecology 31, 857865. 
Stephen, N. (2002) Standardisation of soil quality attributes. Agriculture, Ecosystems and Environment 88, 161-168.

Stott, D.E., Kennedy, A.C. and Cambardella, C.A. (1999) Impact of soil organisms and organic matter on soil structure. In: Lal, R. (ed.) Soil Quality and Soil Erosion. Soil and Water Conservation Society, CRC Press, Boca Raton, Florida, pp. 57-74.

Taylor, H.M. and Terrell, E.E. (1982) Rooting pattern and plant productivity. In: Rechcigl, Jr., M. (ed.) CRC Handbook of Agricultural Productivity, Vol. 1. CRC Press, Boca Raton, Florida, pp. 185-200.

Tian, G., Olimah, O.A., Adeoye, G.O. and Kang, B.T. (2000) Regeneration of earthworm population in a degraded soil by natural and planted fallows under humid tropical conditions. Soil Science Society of America Journal 64, 222-228.

Turco, R.F., Kennedy, A.C. and Jawson, M.D. (1994) Microbial indictors of soil quality. In: Doran, J.W., Coleman, D.C., Bezdicek, D.F. and Stewart, B.A. (eds) Defining Soil Quality for a Sustainable Environment. Soil Science Society of America (SSSA) Special Publication no. 35. SSSA and American Society of Agronomy, Madison, Wisconsin, pp. 73-90.

Wani, S.P., McGill, W.B., Haugen-Kozyra, K. and Juma, N.G. (1994) Increased proportion of active soil $\mathrm{N}$ in Breton loam under cropping systems with forages and green manures. Canadian Journal of Soil Science 74, 67-74.

Wani, S.P., Pathak, P., Jangawad, L.S., Eswaran, H. and Singh, P. (2003) Improved management of Vertisols in the semi-arid tropics for increased productivity and soil carbon sequestration. Soil Use and Management 19, 217-222.

Young, C.E., Crowder, B.M., Shortle, J.S. and Alwang, J.R. (1985) Nutrient management on dairy farms in southeastern Pennsylvania. Journal of Soil and Water Conservation $40,443-445$. 